Marquette University

e-Publications@Marquette

Psychology Faculty Research and Publications

Psychology Department

7-1-2015

Ethnic Microaggressions, Traumatic Stress Symptoms, And Latino Depression: A Moderated Mediational Model

Lucas Torres

Marquette University, lucas.torres@marquette.edu

Joelle T. Taknint

Victoria University of Wellington

Accepted version. Journal of Counseling Psychology, Vol 62, No. 3 (July 2015): 393-401. DOI. (C) 2015 American Psychological Association. Used with permission.

This article may not exactly replicate the final version published in the APA journal. It is not the copy of record. 


\title{
Ethnic Microaggressions, Traumatic Stress Symptoms, And Latino Depression: A Moderated Mediational Model
}

\author{
Lucas Torres \\ Psychology Department, Marquette University \\ Milwaukee, WI \\ Joelle T. Taknint \\ Department of Psychology, Victoria University of Wellington \\ Wellington, New Zealand
}

The Latino population living in the United States continues to grow at an exponential rate. It has been estimated that Latinos constitute $16 \%$ of the total U.S. population and account for approximately $56 \%$ of the nation's growth from 2000 to 2010 (Passel, D'Vera, \& Lopez, 2011). Unfortunately, the mental health disparities evident within this group are not well understood. For instance, Latinos show higher rates of depressive symptomatology when compared to their non-Latino White counterparts (Menselson, Rehkopf, \& Kubzansky, 2008). It has been proposed that exposure to social stressors, such as racial/ethnic discrimination, places an added burden on the lives of ethnic minority individuals (Schwartz \& Meyer, 2010). 
Extensive research has documented the inimical psychological effects of experiencing discrimination (Lee \& Ahn, 2012; Williams \& Mohammed, 2009). However, the mechanism underlying the link between ethnic discrimination and mental health problems, particularly among Latinos, has been largely understudied (Molina, Alegría, \& Mahalingam, 2012). Previous work has proposed that the connection between ethnic discrimination and mental health is explained by heightened emotional stress responses that mediate this relationship. Furthermore, resources, such as ethnic identity and self-efficacy, may moderate the discrimination and stress response link (Pascoe \& Smart Richman, 2009).

A burgeoning interest in the empirical research has sought to examine ethnic microaggressions, or a modern form of discrimination that involves brief and commonplace daily interactions that, whether intentional or unintentional, communicate rudeness and insults or negate the experiential reality of ethnic minority individuals (Sue et al., 2007). It has been suggested that ethnic microaggressions may lead to more severe psychological consequences than overt discrimination (Solórzano, Ceja, \& Yosso, 2000). This may be due in part to the nature of these exchanges, which can be ambiguous, denied, or rationalized as well-intentioned, thus, resulting in a more active or complex appraisal of the situation (Noh, Kaspar, \& Wickrama, 2007; Tran \& Lee, 2014). A recent meta-analysis comparing subtle and overt discrimination reported that both had comparable magnitude estimates concluding that instances of ethnic microaggressions are at least equally damaging to psychological health (Jones, Peddie, Gilrane, King, \& Gray, 2013).

The empirical research examining ethnic microaggressions among Latino groups have, for the most part, employed qualitative methods to explore and identify the different types of microaggressions experienced (see Wong, Derthick, David, Saw, \& Okazaki, 2014 for a review). For instance, Latinos are often treated as perpetual foreigners or have others assume they are undocumented immigrants despite nativity status (Nadal, Mazzula, Rivera, \& FujiiDoe, 2014). Additionally, Latinos often report being treated like a second class citizen, assumptions of inferiority, or ascriptions of intelligence (Rivera, Forquer, \& Rangel, 2010). In terms of demographic differences, Latina women are more likely to experience 
workplace/school microaggressions than Latino men, whereas foreignborn Latinos are more likely to be treated as inferior compared to their U.S.-born counterparts (Nadal, Mazzula, et al., 2014). Latino adolescents have indicated being treated as a second class citizen more often than their Asian American counterparts (Huynh, 2012).

The stress of everyday, unfair treatment is likely to accumulate over time and trigger psychological and physiological responses (Molina et al., 2012). Individuals who report ethnic microaggressions show levels of psychological distress similar to those who experience other interpersonal transgressions such as betrayal and abuse (Schoulte, Schultz, \& Altmaier, 2011). Although more recent work has investigated the psychological impact of ethnic microaggressions among Asian Americans (Ong, Burrow, Fuller-Rowell, Ja, \& Sue, 2013) and African Americans (Torres, Driscoll, \& Burrow, 2010), there remains a lack of studies with Latino samples. Ethnic microaggressions have been associated with mental health problems, particularly depression and lack of positive affect, among a multiethnic sample including Latinos (Nadal, Griffin, Wong, Hamit, \& Rasmus, 2014). Huynh (2012) sampled Latino and Asian American adolescents and reported that the experience of microaggressions, in conjunction with the negative reactions to these experiences, was associated with heightened depressive and somatic symptoms. Furthermore, this study reported that anger and stress functioned as mediators between microaggressions and mental health among these adolescents.

As a way of explaining the underlying mechanism by which discrimination, or ethnic microaggressions in this case, contributes to mental health problems, emotional stress responses have been proposed to function as a mediator (Pascoe \& Smart Richman, 2009). Exposure to chronic and/or high levels of stress may result in a dysregulated stress response pattern that may compromise an individual's ability to effectively manage adverse events (Evans \& Kim, 2007; McEwen, 1998). As an indicator of the emotional stress response, traumatic stress is defined as the negative responses that correspond to an adverse, sudden, and uncontrollable event (Carlson, 1997). Traumatic stress involves the emotional pain associated with stressful events and includes symptoms such as avoidance, arousal, and/or hypervigilance (Carlson, 1997; Carter, 2007). Ethnic discrimination has been thought to lead to traumatic stress symptoms, 
given that such negative events are often hostile, unexpected, and result in a lack of control (Carter, 2007; Flores, Tschann, Dimas, Pasch \& de Groat, 2010). Past research has found a significant relationship between ethnic discrimination and increased traumatic stress symptoms among Latinos (Flores et al., 2010; Pole, Best, Metzler, \& Marmar, 2005). Furthermore, individuals who reported experiencing ethnic microaggressions have also indicated elevated intrusive, avoidance, and hyperarousal symptoms (Schoulte et al., 2011).

The mediational pathways by which ethnic microaggressions can contribute to mental health can also include moderator variables that influence the underlying stress response (Pascoe \& Smart Richman, 2009). Ethnic identity, defined as an individual's self-concept and subjective sense of belonging to an ethnic group, has been associated with positive psychological outcomes, perhaps because it functions as a valuable resource when managing stress (Phinney \& Ong, 2007; Sellers \& Shelton, 2003). A previous meta-analysis reported a modest positive relationship between ethnic identity and psychological wellbeing (Smith \& Silva, 2011). However, the association with mental health symptoms was not as strong as with well-being, leading the authors to conclude that ethnic identity may not have a direct contribution to psychological problems but instead works through other mechanisms.

Within the context of ethnic discrimination, inconsistencies have emerged in the empirical literature with some evidence that ethnic identity was an important buffer to psychological problems (Brittian et al., 20154; Mossakowski, 2003; Shelton et al., 2005) while other work has suggested an exacerbating effect (McCoy \& Major, 2003; Yoo \& Lee, 2008). One study reported that ethnic identity moderated the relationship between ethnic/racial discrimination and traumatic stress symptoms among a multiethnic sample of college students such that high levels were associated with greater symptoms (Khaylis, Waelde, \& Bruce, 2007). As such, the ability of ethnic identity to influence the psychological outcomes associated with ethnic discrimination remains unclear. Unfortunately, the role of ethnic identity as it relates to ethnic microaggressions among Latinos has yet to be examined.

Another important moderator that may impact psychological responses to ethnic microaggressions is an individual's general self-

Journal of Counseling Psychology, Vol 62, No. 3 (July 2015): pg. 393-401. DOI. This article is @ American Psychological Association and permission has been granted for this version to appear in e-Publications@Marquette. American Psychological Association does not grant permission for this article to be further copied/distributed or hosted elsewhere without the express permission from American Psychological Association. 
efficacy. Traditionally, general self-efficacy has been defined as cognitive beliefs regarding one's ability to accomplish a task or cope effectively with life challenges (Bandura, 2001). General self-efficacy refers to a stable sense of personal competence to deal effectively with a variety of stressors and is broadly considered a protective factor (Scholz, Gutiérrez Doña, Sud, \& Schwarzer, 2002). As a resource, individuals with a high level of self-efficacy are thought to interpret demands more as challenges than as threats and respond to physiological arousal in a healthy manner (Jerusalem \& Mittag, 1995).

Research examining general self-efficacy have reported a moderating effect between stress and psychological well-being by which high levels were found to be protective (Lightsey \& Christopher, 1997; Prati, Pietrantoni, \& Cicognani, 2010). However, the bulk of empirical work with Latino participants has sampled adolescent and/or college-aged individuals. Lee and Ahn (2012) conducted a metaanalysis focusing on Latino research studies and found that selfefficacy, among other personal strengths, was strongly and negatively associated with ethnic discrimination and poor mental health outcomes. The majority of research examining ethnic discrimination among Latinos has focused in large part on academic self-efficacy, rather than general self-efficacy, with the bulk of findings reporting a negative relationship (Berkel et al., 2010; Gonzalez, Stein, Kiang, \& Cupito, 2014). Thus, a major gap in the empirical literature includes understanding the role of general self-efficacy within the context of ethnic microaggressions among Latino adults.

The current study sought to examine the moderating and mediational pathways linking ethnic microaggressions to depressive symptoms among Latino adults (see Figure 1 for the conceptual model). Based on previous research, a moderated mediational model was hypothesized such that ethnic microaggressions are associated with increased traumatic stress symptoms, which, in turn, are related to elevated depression. Moreover, it was expected that ethnic identity and general self-efficacy would moderate the mediational pathway or indirect effect. The empirical literature regarding the moderating role of ethnic identity is equivocal, making it difficult to make directional hypotheses. It was anticipated that general self-efficacy would show a buffering effect. The analyses in the present study tested conditional indirect effects regarding the ability of a moderator to influence a

Journal of Counseling Psychology, Vol 62, No. 3 (July 2015): pg. 393-401. DOI. This article is @ American Psychological Association and permission has been granted for this version to appear in e-Publications@Marquette. American Psychological Association does not grant permission for this article to be further copied/distributed or hosted elsewhere without the express permission from American Psychological Association. 
mediational pathway (Hayes, 2013; Preacher, Rucker, \& Hayes, 2007). The main analyses controlled for demographic variables that have been found to be related to depression, namely gender (Otiniano Verissimo, Gee, Ford, \& Iguchi, 2014), income (Kessler et al., 2003), language of survey (Bzostek, Goldman, \& Pebley, 2007), and nativity status (Tillman \& Weiss, 2009).

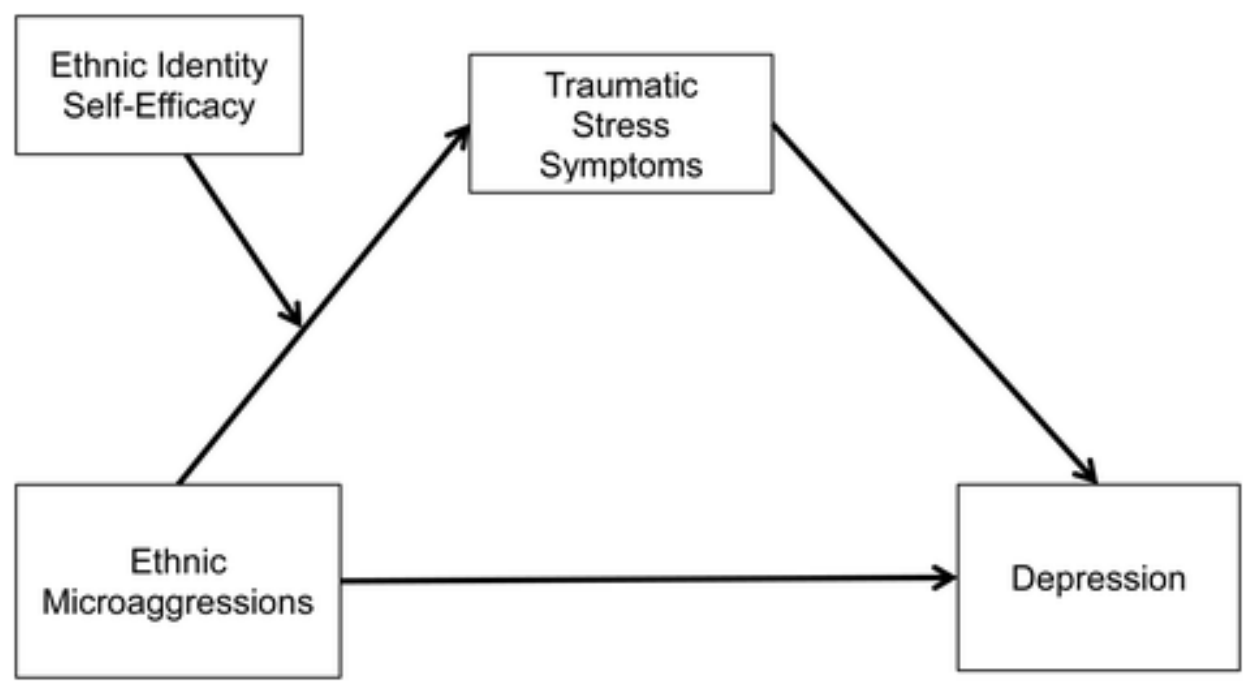

Figure 1. Conceptual model.

\section{Method}

\section{Participants}

The participants in this study were comprised of 113 Latino/a adults (42 male, 67 female, 4 who did not report gender) living in a moderately-sized Midwestern city. Participants ranged in age from 18 to 65 , with a mean age of approximately 34 years $(S D=11.6)$. In terms of ethnic/cultural heritage, $82 \%(n=92)$ of participants identified as Mexican, Mexican American, or Chicano. Other represented ethnic groups included Puerto Rican $(n=15)$ and Central or South Americans $(n=4)$. The majority of the participants $(64 \% ; n$ $=72$ ) identified being born outside of the United States. The mean number of years lived in the United States for this participant pool was $22.9(S D=11.9)$. In terms of socioeconomic status, $11 \%(n=12)$ reported an annual household income of less than $\$ 10,000,18 \%(n=$

Journal of Counseling Psychology, Vol 62, No. 3 (July 2015): pg. 393-401. DOI. This article is (C) American Psychological Association and permission has been granted for this version to appear in e-Publications@Marquette. American Psychological Association does not grant permission for this article to be further copied/distributed or hosted elsewhere without the express permission from American Psychological Association. 
19) had an income of $\$ 10,000--\$ 20,000,35 \%(n=39)$ had an income of $\$ 20,000--\$ 35,000,18 \%(n=19)$ had an income of $\$ 35,000--$ $\$ 50,000$, and another $18 \%(n=19)$ had an income of $\$ 50,000$ or higher. Five participants did not report their household income. Approximately $49 \%(n=54)$ of the sample indicated having some high school or a high school degree (or equivalency). With the exception of three individuals who stated having no high school, the remaining participants reported attending some college/university, having a bachelor's degree (or equivalency), or graduate level education.

\section{Procedures}

Participants in this study were recruited through community events and Latino-serving organizations. The respondents, who selfidentified as being Latino/Latina or Hispanic, completed a paper-andpencil survey packet that included the materials described below. Measures in the survey packet were randomly ordered. Participants finished the survey on average between 20 and $45 \mathrm{~min}$, at which point they were compensated for their time with a $\$ 10$ gift card. The survey was offered in both English and Spanish with $52 \%(n=59)$ of the sample completing the questionnaires in English. The study protocol was approved by, and in compliance with, the sponsoring institution's Institutional Review Board.

\section{Materials}

\section{Ethnic microaggressions}

The Racial and Ethnic Microaggressions Scale (REMS; Nadal, 2011) is a 45-item self-report measure that assesses the frequency of racial/ethnic microaggressions over the past six months. The REMS includes six subscales that examine different types of microaggressions including Assumptions of Inferiority, Second Class Citizen and Assumptions of Criminality, Microinvalidations, Exoticization and Assumptions of Similarity, Environmental Microaggressions, and Workplace and School Microaggressions. Participants are asked to rate each item on a 6-point Likert scale ranging from 0 ( $I$ did not experienced this event) to 5 ( $I$ experienced 
this event 5 or more times). An overall average score is calculated with higher scores indicating a greater frequency of racial/ethnic microaggressions. A previous study has shown that the REMS is reliable with Latino samples reporting a Cronbach's alpha of .91 (Nadal, 2011). The internal consistency coefficient in the present study was .96 (English $a=.97$, Spanish $a=.91$ ). Nadal, Griffin, and colleagues (2014) found that the REMS was significantly associated with the Mental Health Inventory, namely depression and negative affect, among a sample that included Latino adults.

\section{Ethnic identity}

The Multigroup Ethnic Identity Measure-Revised (MEIM-R; Phinney \& Ong, 2007) is a six-item measure used to assess two different aspects of ethnic identity: exploration and commitment. Respondents rate items using a 4-point Likert scale ranging from 1 (strongly disagree) to 4 (strongly agree). For the current study, an overall mean score was calculated with higher scores representing a stronger sense of belonging to the ethnic group. The MEIM-R has been validated across ethnic groups, including Latinos (Yoon, 2011). A previous study showed the MEIM-R to have adequate internal consistency with alphas ranging .81--.88 (Torres, Yznaga, \& Moore, 2011). In the present study a Cronbach's alpha of .83 was found (English $a=.83$, Spanish $a=.85$ ). Yoon (2011) reported that the MEIM-R was positively correlated with positive affect while negatively related to negative affect.

\section{General self-efficacy}

The General Self Efficacy Scale (GSE; Schwarzer \& Jerusalem, 1995 ) is a 10-item measure that assesses an individual's perception of his or her ability to perform across situations. Items are rated on a 4point Likert scale ranging from 1 (not at all true) to 4 (exactly true). Total sum scores are calculated, ranging from 10-40, with higher scores indicating a higher level of self-efficacy. The GSE is one of the most widely used scales of self-efficacy and has been tested internationally, including Spanish-speaking countries, with Cronbach's alpha values ranging from .75-.91 (Scholz et al., 2002). In the current study, the internal consistency coefficient was calculated at .91 (English $a=.89$, Spanish $a=.93)$. Driscoll and Torres (2013) showed 
that the GSE was significantly and negatively associated with depression among Latino adults.

\section{Traumatic stress}

The PTSD Symptoms Scale-Self Report (PSS-SR; Foa, Riggs, Dancu, \& Rothbaum, 1993) is a 17-item self-report measure used to assess the frequency of posttraumatic stress disorder (PTSD) symptoms. The current study used a modified version of the original measure that reworded items to be nontrauma specific so that it could be used with individuals who may not have experienced a traumatic event (Boney-McCoy \& Finkelhor, 1996). Respondents rate the frequency with which they experience a range of symptoms, including avoidance and numbing, re-experiencing, and increased arousal, in the past week using a 4-point Likert scale ranging from 1 (never) to 4 (very often). Average scores are calculated with higher scores indicating a greater number of symptoms. The modified PSS-SR has been used effectively with Latinos with an internal consistency coefficient reported at .94 for the English version and .93 for the Spanish (Torres \& Vallejo, 2015). The Cronbach's alpha for the current study was .92 (English $a=.93$, Spanish $a=.90)$. The PSS-SR has been shown to be associated with increased depression among Latino adults (Torres \& Vallejo, 2015).

\section{Depression}

The Center for Epidemiologic Studies-Depression Scale (CES-D; Radloff, 1977) is a 20-item self-report measure that is used to measure current levels of depressive symptoms in a general population. The items ask participants to rate how often they have endorsed each item in the past week. Responses range from 1 (rarely or none of the time-less than 1 day) to 4 (most or all of the time 5-7 days). The total sum is calculated, with a range from 0 to 60 , where higher scores are indicative of more depressive symptoms.

Researchers have reported sound psychometric properties when using the CES-D with Latino populations, including Spanish versions with a reported Cronbach's alpha of .87 (Torres, 2010). The internal consistency coefficient for the present study is .76 (English $a=.72$, Spanish $a=.81)$. Torres and Vallejo (2015) found that the CES-D was

Journal of Counseling Psychology, Vol 62, No. 3 (July 2015): pg. 393-401. DOI. This article is @ American Psychological Association and permission has been granted for this version to appear in e-Publications@Marquette. American Psychological Association does not grant permission for this article to be further copied/distributed or hosted elsewhere without the express permission from American Psychological Association. 
NOT THE PUBLISHED VERSION; this is the author's final, peer-reviewed manuscript. The published version may be accessed by following the link in the citation at the bottom of the page.

positively associated with a measure of ethnic discrimination in a sample of Latino adults.

\section{Results}

As shown in Table 1, preliminary analyses revealed that participants reported ethnic microaggressions, on average, once in the past six months. The mean REMS score is higher than has been reported in previous research (Nadal, Mazzula, et al., 2014). Ethnic microaggressions were significantly correlated with traumatic stress, ethnic identity, and depression. In terms of ethnic identity, participants reported a strong sense of belonging to the Latino ethnic group. Respondents also showed high general self-efficacy scores suggesting a developed capacity to complete situational tasks. Ethnic identity was significantly correlated with general self-efficacy but neither was significantly associated with depression. The average traumatic stress symptoms fell in the mild to moderate levels. As for depression, CES-D mean scores were in the moderate to high range and just below a commonly used clinical cut-off (CES-D score $\geq 16$; Torres, 2010). Traumatic stress and depression was found to be significantly correlated. No statistically significant differences were found for study variables across gender and nativity status. A statistically significant difference emerged for ethnic microaggressions and language of survey with English respondents reporting higher REMS scores than Spanish participants $[M=1.25(S D=1.04) ; M=$ $0.72(S D=0.57)$, respectively; $t(109)=3.28, p=.001]$. No other variations based on language of survey emerged. A one-way analysis of variance revealed significant differences in CES-D scores across levels of annual household income, $F(5,102)=2.94, p=.02$. Post hoc tests indicated that participants with less than $\$ 10,000$ annual income reported higher CES-D scores than those with an annual income of $\$ 20,000$ or more.

Journal of Counseling Psychology, Vol 62, No. 3 (July 2015): pg. 393-401. DOI. This article is @ American Psychological Association and permission has been granted for this version to appear in e-Publications@Marquette. American Psychological Association does not grant permission for this article to be further copied/distributed or hosted elsewhere without the express permission from American Psychological Association. 
NOT THE PUBLISHED VERSION; this is the author's final, peer-reviewed manuscript. The published version may be accessed by following the link in the citation at the bottom of the page.

Table 1

Correlations and Means of Study Variables

\begin{tabular}{lrrrrr}
\hline & 1 & 2 & 3 & \multicolumn{1}{c}{4} & \multicolumn{1}{c}{5} \\
\hline 1. Ethnic microaggressions & & $.41^{* * *}$ & $.26^{* *}$ & .09 & $.26^{* *}$ \\
2. Traumatic stress symptoms & & & .09 & -.12 & $.61^{* * *}$ \\
3. Ethnic identity & & & & $.25^{* *}$ & .05 \\
4. Self-efficacy & & & & & -.07 \\
5. Depression & 1.00 & 1.56 & 3.17 & 33.03 & 15.57 \\
$M$ & .89 & .52 & .67 & 5.92 & 7.63 \\
$S D$ & & & & &
\end{tabular}

The procedures and recommendations outlined by Hayes (2013) to test conditional indirect effects were used to examine the moderated mediational models. Hayes (2015) proposes an index of moderated mediation as a formal inferential test of whether the moderated mediational model is statistically different from zero. Hayes states that a significant index of moderated mediation is evidence that the "conditional indirect effects estimated at different values of the moderator are significantly different from each other" (p. 4), thus indicating moderated mediation. Assessing conditional indirect effects and calculating the index of moderated mediation is conducted via bootstrapping techniques. Bootstrapping is considered a robust method to examining statistical significance since it effectively controls for Type I error rates, as compared with the causal steps approach and the Sobel test (MacKinnon, Lockwood, Hoffman, West, \& Sheets, 2002; Preacher et al., 2007), without imposing the assumption of normality (Preacher \& Hayes, 2008). The bootstrapping technique is considered a resampling procedure to effect size estimation that takes a large number of samples, 10,000 in the current study, and computes the indirect effect for each. As such, 95\% percentile confidence intervals are constructed. Confidence intervals that do not include the value of zero are considered statistically significant at $p<.05$. Gender, annual household income, language of survey, and nativity status were entered as covariates for all analyses.

The first moderated mediational model tested the ability of traumatic stress to mediate the relationship between ethnic microaggressions and depression with ethnic identity moderating the microaggression and traumatic stress link. As shown in Table 2, ethnic

Journal of Counseling Psychology, Vol 62, No. 3 (July 2015): pg. 393-401. DOI. This article is @ American Psychological Association and permission has been granted for this version to appear in e-Publications@Marquette. American Psychological Association does not grant permission for this article to be further copied/distributed or hosted elsewhere without the express permission from American Psychological Association. 
microaggressions were significantly related to traumatic stress symptoms which, in turn, predicted depression (overall model $R^{2}$ $=.42, F(6,91)=11.16, p<.001)$. The Ethnic Microaggressions $\times$ Ethnic Identity interaction term was statistically significant in predicting traumatic stress symptoms. With all the variables in the model, ethnic microaggressions was not a significant predictor of depression. The index of moderated mediation provides evidence that this moderated mediational model is statistically different from zero. The $95 \%$ confidence intervals did not include zero signifying that the indirect effect was statistically significant at all levels of ethnic identity (1 SD below the mean, at the mean, and $1 S D$ above the mean). A review of the conditional indirect effects at different levels of the moderator (see Table 2) shows that there was a stronger effect at low ethnic identity than at high ethnic identity. Figure 2 illustrates a graphical presentation of the moderating effect such that, in the context of high ethnic microaggressions, low ethnic identity was related to increased traumatic stress symptoms when compared with high ethnic identity.

Table 2

Moderated Mediation Analysis for Ethnic Microaggressions, Traumatic Stress, Ethnic Identity, and Depression

\begin{tabular}{|c|c|c|c|}
\hline & B & $S E \mathrm{~B}$ & $t$ \\
\hline \multicolumn{4}{|l|}{ Mediator-traumatic stress } \\
\hline Predictor: ethnic microaggressions & 1.09 & .31 & $3.54^{* * *}$ \\
\hline Moderator: ethnic identity & .18 & .10 & $1.82^{\dagger}$ \\
\hline Interaction: Ethnic Microaggressions $\times$ Ethnic Identity & -.24 & .09 & $-2.73^{* \bullet}$ \\
\hline \multicolumn{4}{|l|}{ Outcome-depression } \\
\hline Mediator: traumatic stress & 8.23 & 1.44 & $5.71^{\cdots *}$ \\
\hline \multirow[t]{2}{*}{ Predictor: ethnic microaggressions } & .65 & .82 & .79 \\
\hline & Boot indirect $\mathrm{effect} / \mathrm{index}$ & Boot $S E$ & $95 \% \mathrm{CI}$ \\
\hline$-1 S D$ & 4.05 & 1.45 & $1.61,7.32$ \\
\hline Mean & 2.77 & .86 & $1.22,4.57$ \\
\hline$+1 S D$ & 1.49 & 62 & $.55,3.13$ \\
\hline Index of moderated mediation & -1.95 & 1.08 & $-4.53,-.25$ \\
\hline
\end{tabular}

Journal of Counseling Psychology, Vol 62, No. 3 (July 2015): pg. 393-401. DOI. This article is @ American Psychological Association and permission has been granted for this version to appear in e-Publications@Marquette. American Psychological Association does not grant permission for this article to be further copied/distributed or hosted elsewhere without the express permission from American Psychological Association. 
NOT THE PUBLISHED VERSION; this is the author's final, peer-reviewed manuscript. The published version may be accessed by following the link in the citation at the bottom of the page.

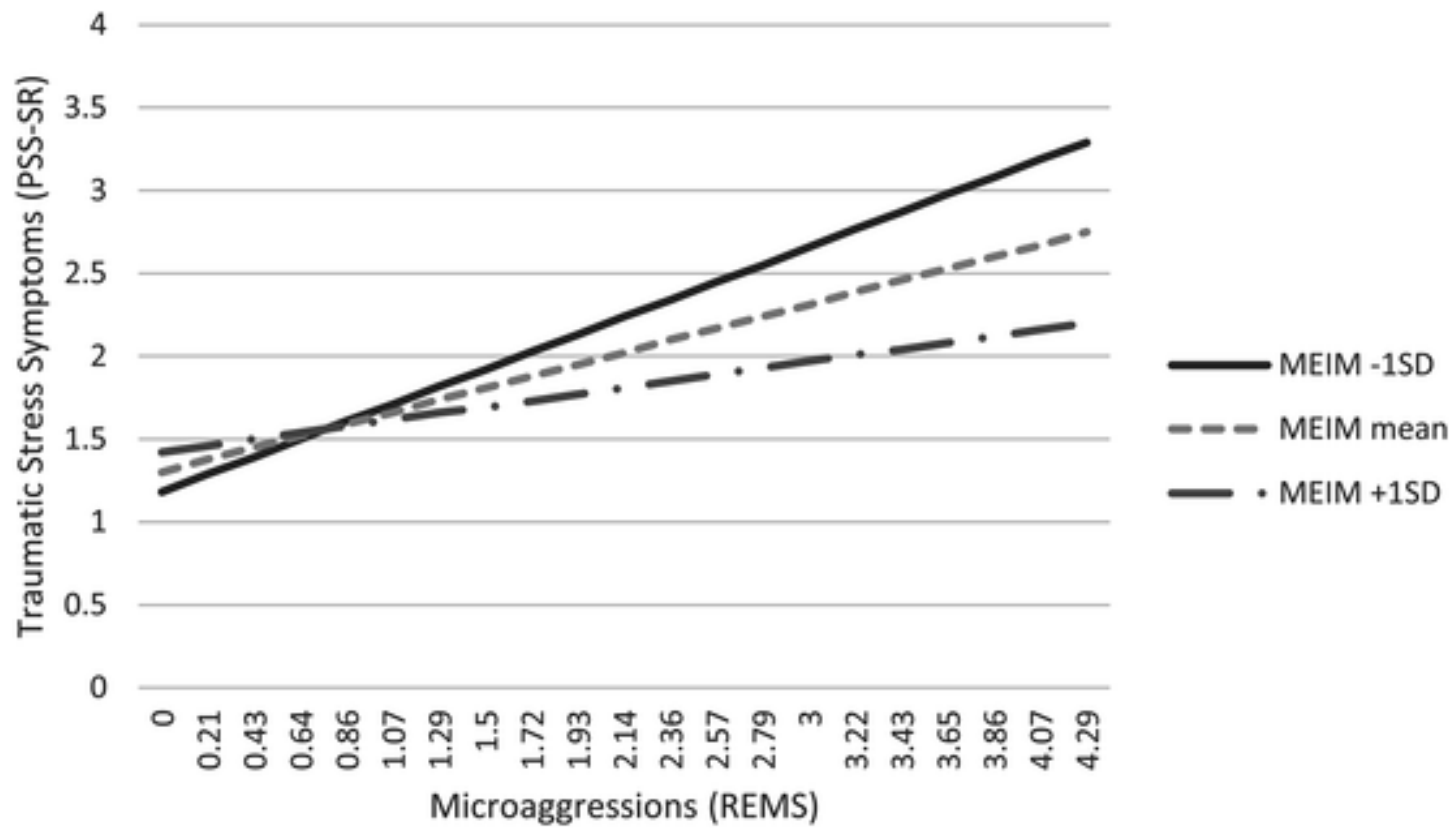

Figure 2. Interaction effect of ethnic microaggressions (REMS) and ethnic identity (MEIM-R) on traumatic stress symptoms (PSS-SR).

The same analysis of moderated mediation as described above was conducted to examine traumatic stress as the mediator between ethnic microaggressions and depression with general self-efficacy as the moderator. As can be seen in Table 3, the results revealed that ethnic microaggressions significantly predicted traumatic stress symptoms which, in turn, significantly predicted depression (overall model $\left.R^{2}=.43, F(6,92)=11.51, p<.001\right)$. The Ethnic Microaggressions $\times$ General Self-Efficacy effect on traumatic stress was statistically significant. The index of moderated mediation revealed a statistically significant model. The $95 \%$ confidence intervals did not include zero at all levels of general self-efficacy (1 SD below the mean, at the mean, and at $1 S D$ above the mean). The conditional indirect effect was stronger at low levels of general self-efficacy than at high levels. Figure 3 illustrates a graphical presentation of the moderating effect suggesting that the combination of high ethnic microaggressions and low general self-efficacy was associated with increased traumatic stress symptoms more so than at high general self-efficacy.

Journal of Counseling Psychology, Vol 62, No. 3 (July 2015): pg. 393-401. DOI. This article is @ American Psychological Association and permission has been granted for this version to appear in e-Publications@Marquette. American Psychological Association does not grant permission for this article to be further copied/distributed or hosted elsewhere without the express permission from American Psychological Association. 
NOT THE PUBLISHED VERSION; this is the author's final, peer-reviewed manuscript. The published version may be accessed by following the link in the citation at the bottom of the page.

Table 3

Moderated Mediation Analysis for Ethnic Microaggressions, Traumatic Stress, Self-Efficacy, and Depression

\begin{tabular}{|c|c|c|c|}
\hline & B & $S E \mathrm{~B}$ & $t$ \\
\hline \multicolumn{4}{|l|}{ Mediator-traumatic stress } \\
\hline Predictor: ethnic microaggressions & 1.29 & .38 & $3.42^{* * *}$ \\
\hline Moderator: self-efficacy & .01 & .01 & 1.06 \\
\hline Interaction: Ethnic Microaggressions $\times$ Self-Efficacy & -.03 & .01 & $-2.76^{* *}$ \\
\hline \multicolumn{4}{|l|}{ Outcome-depression } \\
\hline Mediator: traumatic stress & 8.41 & 1.40 & $6.00^{* * *}$ \\
\hline \multirow[t]{2}{*}{ Predictor: ethnic microaggressions } & .53 & .80 & .65 \\
\hline & Boot indirect $\mathrm{effect} / \mathrm{index}$ & Boot $S E$ & $95 \% \mathrm{CI}$ \\
\hline$-1 S D$ & 3.94 & 1.20 & $1.88,6.60$ \\
\hline Mean & 2.47 & .71 & $1.20,4.03$ \\
\hline$+1 S D$ & .99 & .64 & $.03,2.56$ \\
\hline Index of moderated mediation & -.25 & .11 & $-.49,-.06$ \\
\hline
\end{tabular}

Note. Gender, annual household income, language of survey, and nativity status were covaried in all analyses. $\mathrm{CI}=$ confidence interval.

${ }^{*} p<.01$. ${ }^{* *} p<.001$.

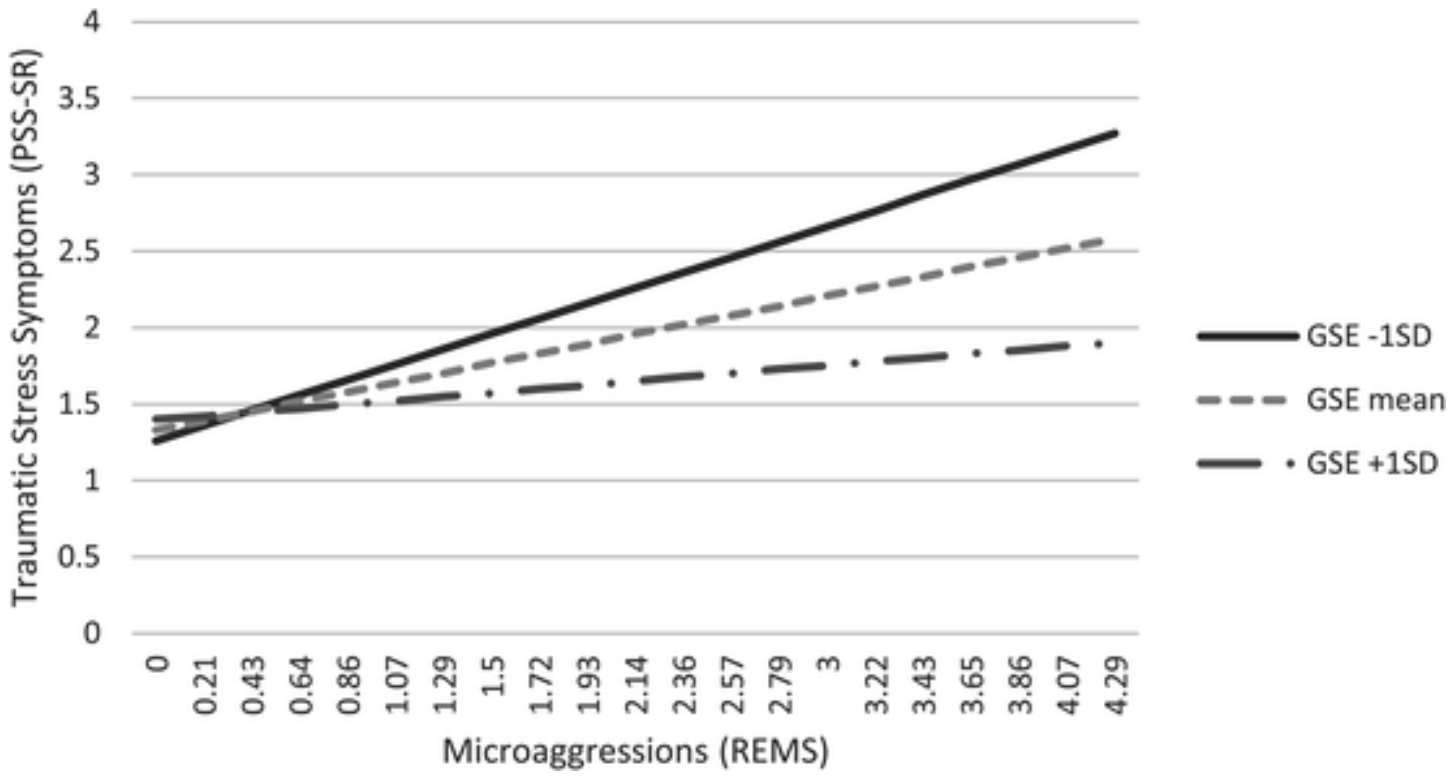

Figure 3. Interaction effect of ethnic microaggressions (REMS) and general self-efficacy (GSE) on traumatic stress symptoms (PSS-SR).

An alternative moderated mediational model was also tested in which depression was the mediator between ethnic microaggressions and traumatic stress symptoms as the outcome variable. With ethnic identity as the moderator, the analyses revealed a nonsignificant index

Journal of Counseling Psychology, Vol 62, No. 3 (July 2015): pg. 393-401. DOI. This article is @ American Psychological Association and permission has been granted for this version to appear in e-Publications@Marquette. American Psychological Association does not grant permission for this article to be further copied/distributed or hosted elsewhere without the express permission from American Psychological Association. 
of moderated mediation (index $=-.07, \mathrm{SE}=.05 ; 95 \% \mathrm{CI}=$ $-.19, .01)$. The results with general self-efficacy as the moderator revealed essentially similar findings with the index of moderated mediation showing marginal statistical significance (index $=-.01, S E$ $=.01 ; 95 \% \mathrm{CI}=-.03,-.0002)$. These analyses provide support for a moderated mediational model by which traumatic stress symptoms mediate the relationship between ethnic microaggressions and depression.

\section{Discussion}

The main objective of the present study was to examine a moderated mediational model that aimed to explain the inimical mental health effects of experiencing ethnic microaggressions for Latino adults. The model implicates the role of emotional stress responses as an underlying mechanism by which these ethnic slights contribute to Latino depression. Further, the situations in which these relationships may be exacerbated are highlighted. The study hypotheses were supported given the main findings showing that ethnic microaggressions were associated with heightened traumatic stress symptoms, which, in turn, were predictive of increased depression. Both ethnic identity and general self-efficacy served to moderate the indirect effect at the ethnic microaggression and traumatic stress link. In other words, the magnitude of traumatic stress connecting ethnic microaggressions to depression was dependent on an individual's level of ethnic identity or general selfefficacy. These results are consistent with past research implicating the negative mental health consequences associated with ethnic microaggressions. However, to our knowledge, this is the first study to test ethnic microaggressions and Latino mental health within a moderated mediational model. The current results advance the empirical research by illustrating the markedly important role that stress responses have on this relationship along with the cultural and individual resources that contribute to this process.

In conjunction with a growing area of research linking traumatic stress to ethnic discrimination (Carter, 2007; Flores et al., 2010), the main findings suggest that symptoms of hypervigilance, arousal, and/or avoidance underlie the process by which ethnic 
microaggressions contributes to mental health problems. Given that ethnic microaggressions can be ambiguous, leaving the individual to determine the intentionality of the interaction, it makes sense that continued exposure to these types of negative events would be associated with increased hyperawareness and vigilance. The strength of this pathway seems to be conditional on the level of ethnic identity and general self-efficacy with low levels of each showing increased risk of experiencing traumatic stress symptoms. As such, Latinos who do not have a strong sense of belonging to their ethnic group or have less well-developed beliefs regarding their ability to manage difficulties may be more vulnerable to the consequences of experiencing an ethnic microaggression. The combination of experiencing subtle covert forms of discrimination along with decreased ethnic-group attachment and self-efficacy contributes to a heightened emotional stress response, which, in turn, can lead to greater depressive symptoms. It is worthwhile to note that neither ethnic identity nor general selfefficacy were significantly correlated with depression but instead appear to have a distal effect on the process that influences mental health.

Given the multifaceted nature of ethnic identity, it can be difficult to deconstruct and determine the specific protective elements within this construct. The current findings do suggest that high ethnic identity, when compared to low levels, can serve to buffer individuals from the psychological consequences of ethnic microaggressions. The emotional component of ethnic identity is thought to be the most important since it refers to a commitment and investment into a particular ethnic group (Phinney \& Ong, 2007). Within the context of ethnic microaggressions, it may be the affective aspect of ethnic identity that buffers individuals from experiencing heightened traumatic stress symptoms. Individuals with low ethnic identity may not be able to manage the emotional aftermath of experiencing ethnic microaggressions.

As an individual resource, general self-efficacy refers to personal mastery or the belief of one's ability to control challenging environmental demands by taking action (Scholz et al., 2002). Low self-efficacy may be indicative of individuals who are generally less adept at initiating active coping skills. Within the context of ethnic microaggressions, Latinos with low self-efficacy may feel less able to 
change their environment or address covert discrimination in an agentic manner. Similar to the pattern observed with ethnic identity, high levels of general self-efficacy can serve as a protective function when experiencing ethnic microaggressions.

Still, it is unclear if ethnic identity and general self-efficacy function by providing strengthening social and emotional support and/or by facilitating the development of specific skills that allow Latinos to better manage ethnic microaggressions. Social support and behavioral coping strategies have been positively associated with selfefficacy in past research (Schwarzer \& Knoll, 2007). It can be argued that ethnic identity and self-efficacy beliefs provide a framework that influences the course of action taken after experiencing an ethnic microaggression, whether that includes seeking social support or implementing a coping behavior. It is important to note that the degree of fit between the stressor and protective resource is influenced by the cultural context (Hobfoll, 2002). Further research should take into account the role of these constructs as they relate to the moderated mediational pathway observed in the current study.

There are several limitations of the current study that should be noted. First, the cross-sectional methodology does not allow for causal conclusions to be made and, thus, highlights the importance of conducting longitudinal studies in the future. Furthermore, self-report measures can be impacted by memory biases and/or social desirability. Second, the relatively low sample size of the current study requires that any conclusions be tempered until further research can corroborate these relationships. The majority of the sample selfidentified as being of Mexican origin, which limits the generalizability of the findings to other Latino subgroups. Finally, the current study assessed symptoms of depression and traumatic stress but did not ascertain diagnosable conditions within the participants. Individuals with clinically diagnosed mental disorders may be more vulnerable to the consequences of daily life stressors including ethnic microaggressions.

The current findings provide insight into the underlying mechanisms that help to explain why ethnic microaggressions, and ethnic discrimination, more broadly, has such a significant and negative psychological impact on the lives of Latino individuals. In

Journal of Counseling Psychology, Vol 62, No. 3 (July 2015): pg. 393-401. DOI. This article is @ American Psychological Association and permission has been granted for this version to appear in e-Publications@Marquette. American Psychological Association does not grant permission for this article to be further copied/distributed or hosted elsewhere without the express permission from American Psychological Association. 
terms of theoretical implications, the present study expands the current knowledge base by providing empirical support for the moderated mediational models previously proposed (cf., Pascoe \& Smart Richman, 2009). The conceptualization of traumatic stress as an indicator of an emotional stress response lends further credence to the type of psychological injury associated with covert forms of discrimination. Future research should seek to examine the various aspects of the stress response in relation to the experience of different types of ethnic microaggressions. As for practical implications, intervention strategies that focus on building one's sense of ethnic identity and general self-efficacy can be an important buffer in the face of unfair treatment.

\section{References}

Bandura, A. (2001). Social cognitive theory: An agentic perspective. Annual Review of Psychology, 52, 1-26. 10.1146/annurev.psych.52.1.1

Berkel, C., Knight, G. P., Zeiders, K. H., Tein, J.-Y., Roosa, M. W., Gonzales, N. A., \& Saenz, D. (2010). Discrimination and adjustment for Mexican American adolescents: A prospective examination of the benefits of culturally-related values. Journal of Research on Adolescence, 20, 893-915. 10.1111/j.1532-7795.2010.00668.x

Boney-McCoy, S., \& Finkelhor, D. (1996). Is youth victimization related to trauma symptoms and depression after controlling for prior symptoms and family relationships? A longitudinal, prospective study. Journal of Consulting and Clinical Psychology, 64, 1406-1416. 10.1037/0022006X.64.6.1406

Brittian, A. S., Kim, S. Y., Armenta, B. E., Lee, R. M., Umaña-Taylor, A. J., Schwartz, S. J., . . .Hudson, M. L. (2015). Do dimensions of ethnic identity mediate the association between perceived ethnic group discrimination and depressive symptoms?Cultural Diversity \& Ethnic Minority Psychology, 21, 41-53.

Bzostek, S., Goldman, N., \& Pebley, A. (2007). Why do Hispanics in the USA report poor health?Social Science \& Medicine, 65, 990-1003. 10.1016/j.socscimed.2007.04.028

Carlson, E. B. (1997). Trauma assessments: A clinician's guide. New York, NY: Guilford Press.

Carter, R. T. (2007). Racism and psychological and emotional injury: Recognizing and assessing race-based traumatic stress. The Counseling Psychologist, 35, 13-105. 10.1177/0011000006292033

Driscoll, M. W., \& Torres, L. (2013). Acculturative stress and Latino depression: The mediating role of behavioral and cognitive resources.

Journal of Counseling Psychology, Vol 62, No. 3 (July 2015): pg. 393-401. DOI. This article is @ American Psychological Association and permission has been granted for this version to appear in e-Publications@Marquette. American Psychological Association does not grant permission for this article to be further copied/distributed or hosted elsewhere without the express permission from American Psychological Association. 
NOT THE PUBLISHED VERSION; this is the author's final, peer-reviewed manuscript. The published version may be accessed by following the link in the citation at the bottom of the page.

Cultural Diversity and Ethnic Minority Psychology, 19, 373-382. $10.1037 / \mathrm{a} 0032821$

Evans, G. W., \& Kim, P. (2007). Childhood poverty and health: Cumulative risk exposure and stress dysregulation. Psychological Science, 18, 953-957. 10.1111/j.1467-9280.2007.02008.x

Flores, E., Tschann, J. M., Dimas, J. M., Pasch, L. A., \& de Groat, C. L. (2010). Perceived racial/ethnic discrimination, posttraumatic stress symptoms, and health risk behaviors among Mexican American adolescents. Journal of Counseling Psychology, 57, 264-273. $10.1037 / \mathrm{a} 0020026$

Foa, E. B., Riggs, D., Dancu, C., \& Rothbaum, B. (1993). Reliability and validity of a brief instrument for assessing post-traumatic stress disorder. Journal of Traumatic Stress, 6, 459-473. $10.1002 /$ jts. 2490060405

Gonzalez, L. M., Stein, G. L., Kiang, L., \& Cupito, A. M. (2014). The impact of discrimination and support on developmental competencies in Latino adolescents. Journal of Latina/o Psychology, 2, 79-91.

Hayes, A. F. (2013). Introduction to mediation, moderation, and conditional process analysis: A regression-based approach. New York, NY: Guilford Press.

Hayes, A. F. (2015). An index and test of linear moderated mediation. Multivariate Behavioral Research, 50, 1-22.

Hobfoll, S. E. (2002). Social and psychological resources and adaptation. Review of General Psychology, 6, 307-324. 10.1037/10892680.6.4.307

Huynh, V. W. (2012). Ethnic microaggressions and the depressive and somatic symptoms of Latino and Asian American adolescents. Journal of Youth and Adolescence, 41, 831-846.

Jerusalem, M., \& Mittag, W. (1995). Self-efficacy in stressful life transitions. In A.Bandura (Ed.), Self-efficacy in changing societies (pp. 177-201). New York, NY: Cambridge University Press.

Jones, K. P., Peddie, C. I., Gilrane, V. L., King, E. B., \& Gray, A. L. (2013). Not so subtle: A meta-analytic investigation of the correlates of subtle and overt discrimination. Journal of Management. Advance online publication. 10.1177/0149206313506466

Kessler, R. C., Berglund, P., Demler, O., Jin, R., Koretz, D., Merikangas, K. R., . . .Wang, P. S., \& the National Comorbidity Survey Replication. (2003). The epidemiology of major depressive disorder: Results from the National Comorbidity Survey Replication (NCS-R). JAMA: Journal of the American Medical Association, 289, 3095-3105.

10.1001/jama.289.23.3095

Journal of Counseling Psychology, Vol 62, No. 3 (July 2015): pg. 393-401. DOI. This article is @ American Psychological Association and permission has been granted for this version to appear in e-Publications@Marquette. American Psychological Association does not grant permission for this article to be further copied/distributed or hosted elsewhere without the express permission from American Psychological Association. 
Khaylis, A., Waelde, L., \& Bruce, E. (2007). The role of ethnic identity in the relationship of race-related stress to PTSD symptoms among young adults. Journal of Trauma \& Dissociation, 8, 91-105.

Lee, D. L., \& Ahn, S. (2012). Discrimination against Latina/os: A metaanalysis of individual-level resources and outcomes. The Counseling Psychologist, 40, 28-65. 10.1177/0011000011403326

Lightsey, O. R., Jr., \& Christopher, J. C. (1997). Stress buffers and dysphoria in a non-western population. Journal of Counseling \& Development, 75, 451-459. 10.1002/j.1556-6676.1997.tb02361.x

MacKinnon, D. P., Lockwood, C. M., Hoffman, J. M., West, S. G., \& Sheets, V. (2002). A comparison of methods to test mediation and other intervening variable effects. Psychological Methods, 7, 83-104. 10.1037/1082-989X.7.1.83

McCoy, S. K., \& Major, B. (2003). Group identification moderates emotional responses to perceived prejudice. Personality and Social Psychology Bulletin, 29, 1005-1017. 10.1177/0146167203253466

McEwen, B. S. (1998). Protective and damaging effects of stress mediators. The New England Journal of Medicine, 338, 171-179. 10.1056/NEJM199801153380307

Menselson, T., Rehkopf, D. H., \& Kubzansky, L. D. (2008). Depression among Latinos in the United States: A meta-analytic review. Journal of Consulting and Clinical Psychology, 76, 355-366. 10.1037/0022006X.76.3.355

Molina, K. M., Alegría, M., \& Mahalingam, R. (2013). A multiple-group path analysis of the role of everyday discrimination on self-rated physical health among Latina/os in the USA. Annals of Behavioral Medicine, 45, 33-44. 10.1007/s12160-012-9421-2

Mossakowski, K. N. (2003). Coping with perceived discrimination: Does ethnic identity protect mental health?Journal of Health and Social Behavior, 44, 318-331. 10.2307/1519782

Nadal, K. L. (2011). The Racial and Ethnic Microaggressions Scale (REMS): Construction, reliability, and validity. Journal of Counseling Psychology, 58, 470-480. 10.1037/a0025193

Nadal, K. L., Griffin, K. E., Wong, Y., Hamit, S., \& Rasmus, M. (2014). The impact of racial microaggressions on mental health: Counseling implication for clients of color. Journal of Counseling \& Development, 92, 57-66. 10.1002/j.1556-6676.2014.00130.x

Nadal, K. L., Mazzula, S. L., Rivera, D. P., \& Fujii-Doe, W. (2014). Microaggressions and Latina/o Americans: An analysis of nativity, gender, and ethnicity. Journal of Latina/o Psychology, 2, 67-78.

Noh, S., Kaspar, V., \& Wickrama, K. A. S. (2007). Overt and subtle racial discrimination and mental health: Preliminary findings for Korean

Journal of Counseling Psychology, Vol 62, No. 3 (July 2015): pg. 393-401. DOI. This article is @ American Psychological Association and permission has been granted for this version to appear in e-Publications@Marquette. American Psychological Association does not grant permission for this article to be further copied/distributed or hosted elsewhere without the express permission from American Psychological Association. 
NOT THE PUBLISHED VERSION; this is the author's final, peer-reviewed manuscript. The published version may be accessed by following the link in the citation at the bottom of the page.

immigrants. American Journal of Public Health, 97, 1269-1274. 10.2105/AJPH.2005.085316

Ong, A. D., Burrow, A. L., Fuller-Rowell, T. E., Ja, N. M., \& Sue, D. W. (2013). Racial microaggressions and daily well-being among Asian Americans. Journal of Counseling Psychology, 60, 188-199. 10.1037/a0031736

Otiniano Verissimo, A. D., Gee, G. C., Ford, C. L., \& Iguchi, M. Y. (2014). Racial discrimination, gender discrimination, and substance abuse among Latina/os nationwide. Cultural Diversity and Ethnic Minority Psychology, 20, 43-51. 10.1037/a0034674

Pascoe, E. A., \& Smart Richman, L. (2009). Perceived discrimination and health: A meta-analytic review. Psychological Bulletin, 135, 531-554. $10.1037 / \mathrm{a} 0016059$

Passel, J. S., D'Vera, C., \& Lopez, H. (2011). Hispanics account for more than half of nation's growth in past decade. Retrieved from Pew Hispanic Center website: http://pewhispanic.orgh/files/reports/140.pdf. 2011

Phinney, J. S., \& Ong, A. D. (2007). Conceptualization and measurement of ethnic identity: Current status and future directions. Journal of Counseling Psychology, 54, 271-281. 10.1037/0022-0167.54.3.271

Pole, N., Best, S. R., Metzler, T., \& Marmar, C. R. (2005). Why are Hispanics at greater risk for PTSD?Cultural Diversity and Ethnic Minority Psychology, 11, 144-161. 10.1037/1099-9809.11.2.144

Prati, G., Pietrantoni, L., \& Cicognani, E. (2010). Self-efficacy moderates the relationship between stress appraisal and quality of life among rescue workers. Anxiety, Stress \& Coping: An International Journal, 23, 463470. $10.1080 / 10615800903431699$

Preacher, K. J., \& Hayes, A. F. (2008). Asymptotic and resampling strategies for assessing and comparing indirect effects in multiple mediator models. Behavior Research Methods, 40, 879-891. 10.3758/BRM.40.3.879

Preacher, K. J., Rucker, D. D., \& Hayes, A. F. (2007). Addressing moderated mediation hypotheses: Theory, method, and prescriptions. Multivariate Behavioral Research, 42, 185-227. 10.1080/00273170701341316

Radloff, L. S. (1977). The CES-D Scale: A self-report depression scale for research in the general population. Applied Psychological Measurement, 1, 385-401. 10.1177/014662167700100306

Rivera, D. P., Forquer, E. E., \& Rangel, R. (2010). Microaggressions and the life experience of Latina/o Americans. In D. W.Sue (Ed.), Microaggressions and marginality: Manifestations, dynamics, and impact (pp. 59-83). New York, NY: Wiley.

Scholz, U., Gutiérrez Doña, B., Sud, S., \& Schwarzer, R. (2002). Is general self-efficacy a universal construct? Psychometric findings from 25 countries. European Journal of Psychological Assessment, 18, 242251. 10.1027//1015-5759.18.3.242

Journal of Counseling Psychology, Vol 62, No. 3 (July 2015): pg. 393-401. DOI. This article is @ American Psychological Association and permission has been granted for this version to appear in e-Publications@Marquette. American Psychological Association does not grant permission for this article to be further copied/distributed or hosted elsewhere without the express permission from American Psychological Association. 
Schoulte, J. C., Schultz, J. M., \& Altmaier, E. M. (2011). Forgiveness in response to cultural microaggressions. Counselling Psychology Quarterly, 24, 291-300. 10.1080/09515070.2011.634266

Schwartz, S., \& Meyer, I. H. (2010). Mental health disparities research: The impact of within and between group analyses on tests of social stress hypotheses. Social Science \& Medicine, 70, 1111-1118. 10.1016/j.socscimed.2009.11.032

Schwarzer, R., \& Jerusalem, M. (1995). Generalized Self-Efficacy Scale. In J.Weinman, S.Wright, \& M.Johnston (Eds.), Measures in health psychology: A user's portfolio. Causal and control beliefs (pp. 35-37). Windsor, UK: NFER-Nelson.

Schwarzer, R., \& Knoll, N. (2007). Functional roles of social support within the stress and coping process: A theoretical and empirical overview. International Journal of Psychology, 42, 243-252.

Sellers, R. M., \& Shelton, J. N. (2003). The role of racial identity in perceived racial discrimination. Journal of Personality and Social Psychology, 84, 1079-1092. 10.1037/0022-3514.84.5.1079

Shelton, J. N., Yip, T., Eccles, J. S., Chatman, C. M., Fuligni, A. J., \& Wong, C. (2005). Ethnic identity as a buffer of psychological adjustment to stress. In G.Downey, J. S.Eccles, \& C. M.Chatman (Eds.), Navigating the future: Social identity, coping, and life tasks (pp. 96-115). New York, NY: Russell Sage Foundation.

Smith, T. B., \& Silva, L. (2011). Ethnic identity and personal well-being of people of color: A meta-analysis. Journal of Counseling Psychology, 58, 42-60. 10.1037/a0021528

Solórzano, D., Ceja, M., \& Yosso, T. (2000). Critical race theory, racial microaggressions, and campus racial climate: The experiences of African American college students. Journal of Negro Education, 69, 6073.

Sue, D. W., Capodilupo, C. M., Torino, G. C., Bucceri, J. M., Holder, A. M. B., Nadal, K. L., \& Esquilin, M. (2007). Racial microaggressions in everyday life: Implications for clinical practice. American Psychologist, 62, 271-286. 10.1037/0003-066X.62.4.271

Tillman, K. H., \& Weiss, U. K. (2009). Nativity status and depressive symptoms among Hispanic young adults: The role of stress exposure. Social Science Quarterly, 90, 1228-1250. 10.1111/j.15406237.2009.00655.x

Torres, L. (2010). Predicting levels of Latino depression: Acculturation, acculturative stress, and coping. Cultural Diversity and Ethnic Minority Psychology, 16, 256-263. 10.1037/a0017357

Torres, L., Driscoll, M. W., \& Burrow, A. L. (2010). Racial microaggressions and psychological functioning among highly achieving African-

Journal of Counseling Psychology, Vol 62, No. 3 (July 2015): pg. 393-401. DOI. This article is @ American Psychological Association and permission has been granted for this version to appear in e-Publications@Marquette. American Psychological Association does not grant permission for this article to be further copied/distributed or hosted elsewhere without the express permission from American Psychological Association. 
NOT THE PUBLISHED VERSION; this is the author's final, peer-reviewed manuscript. The published version may be accessed by following the link in the citation at the bottom of the page.

Americans: A mixed-methods approach. Journal of Social and Clinical Psychology, 29, 1074-1099. 10.1521/jscp.2010.29.10.1074

Torres, L., \& Vallejo, L. G. (2015). Ethnic discrimination and latino depression: The mediating role of traumatic stress symptoms and alcohol use. Cultural Diversity and Ethnic Minority Psychology. Advance online publication. 10.1037/cdp0000020

Torres, L., Yznaga, S. D., \& Moore, K. M. (2011). Discrimination and Latino psychological distress: The moderating role of ethnic identity exploration and commitment. American Journal of Orthopsychiatry, 81, 526-534.

Tran, A. G. T., \& Lee, R. M. (2014). You speak English well! Asian Americans' reactions to an exceptionalizing stereotype. Journal of Counseling Psychology, 61, 484-490.

Williams, D. R., \& Mohammed, S. A. (2009). Discrimination and racial disparities in health: Evidence and needed research. Journal of Behavioral Medicine, 32, 20-47. 10.1007/s10865-008-9185-0

Wong, G., Derthick, A. O., David, E. J. R., Saw, A., \& Okazaki, S. (2014). The what, the why, and the how: A review of racial microaggressions research in psychology. Race and Social Problems, 6, 181-200. $10.1007 / \mathrm{s} 12552-013-9107-9$

Yoo, H. C., \& Lee, R. (2008). Does ethnic identity buffer or exacerbate the effects of frequent racial discrimination on situational well-being of Asian Americans?Journal of Counseling Psychology, 55, 63-74. 10.1037/0022-0167.55.1.63

Yoon, E. (2011). Measuring ethnic identity in the ethnic identity scale and the multigroup ethnic identity measure-Revised. Cultural Diversity and Ethnic Minority Psychology, 17, 144-155. 10.1037/a0023361

Journal of Counseling Psychology, Vol 62, No. 3 (July 2015): pg. 393-401. DOI. This article is @ American Psychological Association and permission has been granted for this version to appear in e-Publications@Marquette. American Psychological Association does not grant permission for this article to be further copied/distributed or hosted elsewhere without the express permission from American Psychological Association. 